\title{
De Viagem ao Mar absoluto: \\ caminhos do mar em Cecília Meireles
}

p. $63-81$

Camila Marchioro $^{1}$

\section{Resumo}

Foram escolhidos para este estudo acerca do mar em Cecília Meireles três livros da autora: Viagem (1939), Vaga música (1942) e Mar absoluto e outros poemas (1945). Os dois primeiros foram analisados na sua totalidade, enquanto que no último a atenção voltou-se somente para o poema "Mar Absoluto". Os livros são os três primeiros da fase madura da autora e apresentam uma consistência, coesão e continuidade temática que propiciaram as comparações entre eles. A abordagem aqui feita apoia-se na Filosofia Perene, estabelecendo assim um diálogo com algumas culturas do extremo Oriente na tentativa de fazer jus ao vasto conhecimento de mundo de Cecília Meireles, mostrando como o mar ceciliano se transfigura poeticamente até se tornar símbolo do Absoluto.

Palavras-chave: Cecília Meireles. Mar absoluto. Filosofia Perene. Mar.

\begin{abstract}
Viagem (1939), Vaga música (1942) and Mar absoluto e outros poemas (1945) are the three books by Cecilia Meireles chosen for this study about the images of the sea in her poetry. The first two were analyzed in its entirety while in the latter only the poem "Mar absoluto" was closely analyzed. These books are the first three that compose the mature phase of the author. They have a consistency and a thematic cohesion which enable making comparisons between them. The approach adopted in this study is based on Perennial Philosophy, thus establishing a dialogue with different cultures and peoples in an attempt to contemplate Cecilia Meireles' vast knowledge of the world. The objective of this work is to show how the cecilian sea is poetically transformed into a symbol of the Absolute.
\end{abstract}

Keywords: Cecília Meireles. Absolute Sea. Perennial Philosophy. Sea.

\section{Introdução}

"Deus te proteja, Cecília, / Que tudo é mar - e mais nada". Este verso do poema "Beira Mar" revela a centralidade que o mar assume na poesia de Cecília Meireles. É o eu-lírico "Cecília, moradora das areias" que entende que tudo é mar, assim revelando os fortes laços entre autor e obra e redimensionando poeticamente certos elementos da vida:

\begin{abstract}
Sou moradora das areias, de altas espumas: os navios passam pelas minhas janelas como o sangue das minhas veias, como os peixinhos nos rios...
\end{abstract}

Não têm velas e têm velas;

e o mar tem e não tem sereias;

1 Doutoranda na Universidade Federal do Paraná (UFPR). Professora substituta no Departamento de Polonês e Letras Clássicas, da UFP. 
e eu navego e estou parada,

vejo mundos e estou cega,

porque isto é mal de familia,

ser de areia, de água, de ilha...

$E$ até sem barco navega

quem para o mar foi fadada.

Deus te proteja, Cecilia,

que tudo é mar - e mais nada.

(Mar absoluto e outros poemas, 2001, p.488)

Dentre tantos simbolismos que o mar assumiu na poesia e literatura, em Cecília Meireles ocorre que o eu-lírico, ao se ver refletido no mar, vislumbra a possibilidade de desenrolarse eternamente tal e qual o movimento das ondas, sendo como o mar ou estando disposto a desbravá-lo, navegá-lo, todavia o afogamento é sempre um risco.

No poema acima, a imagem que se eleva para o leitor é a de alguém perdido em alto-mar. Entretanto, ao afirmar que os barcos "Não têm velas e têm velas; / e o mar tem e não tem sereias", o eu-lírico abre espaço para um entendimento metafórico dos temas marítimos, de modo que o mar passa a simbolizar também a jornada da própria vida: "E até sem barco navega / quem para o mar foi fadada."

Fascinados pelos mistérios e pela força do mar, os mais diversos povos retrataram sua relação com essa potente força da natureza por meio de contos, cantos, poemas, lendas, épicos, romances. Um dos que mais expressou literariamente esta relação ambivalente foi o povo português. Das cantigas de amigo, passando por Camões e Fernando Pessoa, até hoje os lusos carregam o mar em seus versos. Assim como seus antepassados portugueses, Cecília Meireles empreendeu uma viagem tanto sobre os mares reais quanto nas águas de seu próprio pensamento, metaforicamente. Construiu um eu-lírico pastor de si mesmo, na tentativa de acalmar as torrentes das aflições até compreender que a única saída era de fato mergulhar no Mar Absoluto e mesclar-se a ele, assumindo em si as características e naturezas das águas, ar e nuvens. A sua poesia mostra a possibilidade da eternidade diante de um mundo material e a tentativa de equilibrar-se entre a vida mesquinha dos homens da Terra e a vastidão do mar eterno.

As mortes ocorridas na família da autora (orfandade e a morte precoce do primeiro marido), desde a infância impeliram-na para as areias de uma praia solitária. Seu caminho, como revela o poema supracitado, era para e pelo mar a fim de buscar a si mesma. Nessa busca, deparou-se com um conhecimento compartilhado e desabrochado nas mais diversas culturas ao longo de séculos (leu desde o místico cristão São João da Cruz aos Vedas da literatura sânscrita). Cecília Meireles encontrara ali as várias chaves que abririam a mesma porta. Ainda que variassem os modos de relatar, de se relacionar e de entender o fato, o conhecimento passado por meio dos textos aos quais se voltava a autora era o mesmo: há uma verdade perene e eterna que a tudo subjaz; há algo que está em tudo; que tudo gera, mas não é gerado; há algo a que pertencemos e não é pertencido; criador de si mesmo e de onde tudo emana.

Como descrever a imensidão do que é Absoluto? Como falar daquilo que seria a origem de si mesmo? "O dançarino e sua dança? " Cecília Meireles foi uma das ousadas mentes que tentaram retratar o Absoluto de maneira poética. Disso decorre uma poesia vasta, tão multiforme quanto o próprio mar, motivo e símbolo maior de sua poética nos primeiros três livros de sua fase madura: Viagem (1939), Vaga música (1942) e Mar absoluto e outros poemas (1945).

A crítica tratou das questões do tempo nos versos cecilianos, da sua metafísica, chamou-a mística, traçou suas influências no Oriente, 
no Ocidente, em Portugal e na Índia, falou da importância do mar, da presença de uma certa religiosidade e assim abriu caminho para ampliarmos as análises de sua produção poética. A autora tinha grande conhecimento de folclore e se interessava pelos povos e suas culturas, dedicandose à tarefa de aprender diferentes línguas a fim de melhor reconhecer o outro: "Gosto de estudar o que me dá conhecimento melhor das pessoas, do mundo, da unidade. Por meio dos idiomas e do folclore, vejo até que ponto somos todos filhos de Deus. A passagem do mundo mágico para o mundo lógico me encanta." (Cecília Meireles em sua última entrevista, concedida ao jornalista Pedro Bloch em maio de 1964. Grifo nosso).

Os símbolos de sua poesia, portanto, estão além da simbologia construída dentro dos limites da própria literatura. Nesse sentido, Cecília Meireles dialoga com poetas, mas também com filósofos, monges, santos, vivos e mortos. Sua poesia abarca náufragos e navegadores.

O budismo, hinduísmo, estoicismo, judaísmo e neoplatonismo (entre outros) foram assuntos de interesse da escritora. Esses aqui citados tratam do Absoluto de diferentes modos em algumas de suas vertentes e propõem caminhos que permitam a união do indivíduo com aquilo que seria a substância do universo. São caminhos para tal união o desapego, a renúncia, a dissolução da ideia de ego, a destruição das ilusões e desejos a fim de livrar-se do sofrimento. Esses temas foram abordados por Dillip Loundo em seu ensaio de 2007, "Cecília Meireles e a Índia: Viagem e Meditação Poética”, a partir da relação da poeta com a Índia. Tais aspectos também foram notados por outros críticos, que a princípio relacionaram as temáticas de um certo ascetismo a uma vertente cristã devido à relação de Cecília Meireles com o grupo da revista Festa. Dada a grande possibilidade de associar esses temas centrais da primeira fase de sua madura poesia com diversas filosofias e culturas, é que se propôs aqui o uso da Filosofia Perene ${ }^{2}$.

A fim de ilustrar com maior precisão o objeto da Filosofia Perene, vejamos uma famosa e importante anedota brâmane da tradição sânscrita recontada por Robert Heinrich Zimmer (18901943) em Filosofias da Índia, 1951.

Era uma vez Svetaketu Aruneya. Aos doze anos seu pai lhe disse que fosse viver a vida de um estudante do conhecimento sagrado e o enviou para ser um brâmane. Ao voltar, com vinte e quatro anos, tiveram a seguinte conversa:

\footnotetext{
"Svetaketu, meu querido, já que agora estás envaidecido, te acreditas

erudito e és orgulhoso, pediste também aquele ensinamento mediante $\mathrm{o}$

qual o que não tem sido ouvido chega a ser ouvido, o que não se pensou

vem a ser pensado, o que não se entendeu vem a ser entendido?"

"Imploro, senhor, qual é esse ensinamento?"

"Assim como, meu querido, por um pedaço de argila se pode conhecer

tudo o que é feito de argila (...) tal como por um ornamento de cobre

pode se conhecer tudo que é feito de cobre (...) assim é, meu querido,

este ensinamento"

"Em verdade, aqueles homens dignos não sabiam disso; caso o soubessem

por que não mo teriam contado? Mas tu, senhor, conta-me!"

"Assim seja, (...) traze-me um figo de lá."

"Aqui está!"

"Divide-o."

"Está dividido, senhor."

"Que vês aí?"

"Estas sementes muito pequenas, senhor."

"Divide uma delas, por favor. (...) Que vês aí?"

"Absolutamente nada, senhor."

"Em verdade, meu querido, esta utilíssima essência que tu não percebes;
}

2 O termo "Philosophia Perennis" foi retomado por Gottfried Wilhelm Leibniz (1646-1716), com o intuito de designar uma filosofia comum que faria parte de várias religiões. A popularização do termo se deveu a Aldous Huxley (1894-1963) em seu livro A Filosofia Perene, de 1945. Para este escritor o termo seria usado para descrever "a metafísica que reconhece uma Divina Realidade substancial ao mundo das coisas, (...); a ética que coloca a finalidade do homem no conhecimento da Base imanente e transcendente de todo o ser - a coisa é imemorial e universal.” (HUXLEY, 1971, p. 01). 
em verdade, meu querido, desta utilíssima essência é que surge esta

grande figueira sagrada. Acredita-me, meu querido, isso que é a essência

mais sutil, este mundo inteiro tem isso como seu Eu. Isso é a Realidade.

Isso é o atman. Aquilo tu és (tat tvam asi), Svetaketu." (ZIMMER, 2008, p.245-246).

A partir de uma visão não dualista, segundo o relato de Zimmer, compreende-se que o princípio supremo (o divino referido neste trabalho como Absoluto) é inerente a todos os seres, subjacente a eles, sendo também seu fundamento. Todavia é ao mesmo tempo também invisível e sem substância. Então, ainda que pareça se transfigurar nas formas do mundo (assim como a argila pode ser matéria para muitos potes), as formas visíveis seriam apenas transformações do Absoluto e como tal não devemos limitar nossa atenção ao espetáculo de suas transfigurações (ZIMMER, 2008, p.247). Sendo assim, a Filosofia Perene relaciona-se primeiramente ao Absoluto e, ainda, ao múltiplo mundo da matéria, vidas e pensamentos. No entanto, a natureza da unidade não pode ser apreendida diretamente. Essa filosofia refere ainda que é desejável conhecer a base de tudo (Absoluto), não apenas dentro da alma, mas também fora do mundo e da alma (HUXLEY, 1971, p.09), nas suas variadas formas.

Aqueles que trabalharam com a influência da Índia em Cecília Meireles puderam aproximar os temas de sua poesia às práticas de origem sânscrita, entretanto sabe-se que a autora jamais filiou-se a alguma religião e que suas predileções temáticas não se restringiram à tradição védica. Conhecedora de yoga, mas também da Cabala e leitora de São João da Cruz, muitas vezes os temas de sua poesia foram adjetivados pela crítica como "místicos". Se definirmos misticismo/ mística como sendo a busca da comunhão com o Absoluto (divindade, verdade espiritual) através da comunhão direta, intuição, instinto ou insight ${ }^{3}$ pode-se, de certo modo, tentar avançar um pouco além nos objetivos de uma crítica que assim adjetivou a obra de Meireles.

Em Poesia e estilo de Cecília Meireles, ao falar sobre "Noturno de Amor", poema do livro Nunca Mais...e poema dos poemas (1923), Leodegário A. de Azevedo Filho afirmou: "Poesia aérea e vaga, lânguida e fluida, numa atmosfera intimista de penumbra, perdida no sonho... Ao mesmo tempo mística e sensual(...)" (AZEVEDO FILHO, 1970, p.26). O crítico não definiu o termo "mística", provavelmente usando-o em seu sentido comum intuindo que o leitor compartilhasse da mesma ideia sobre o que seria "mística". Já sobre o livro Baladas para El-Rei (1925), Azevedo disse: "Misticismo, solidão, penumbra, melancolia, tristeza, abstração, consciência e temor da fugacidade do tempo, o sonho... tudo isso caracteriza a temática das Baladas" (Idem, p.30). Bastante sensível à manifestação poética de Cecília Meireles, o crítico vislumbrou em meio às nuvens de uma poesia assaz imprecisa aquilo que era a sua consistência: filosofia e mística. Portanto seriam decorrentes daí as demais temáticas também apontadas por ele, tais como fugacidade do tempo e renúncia. Nas análises dos livros mais maduros da autora, Azevedo Filho apontou ainda para uma recorrente busca pelo "mistério", ou "mistérios da vida", elementos que não deixam de estar

3 A palavra "misticismo" e o conceito de "místico" assumiram os mais variados contornos no decorrer da história da humanidade. O termo sofreu muitas deturpações ao longo dos séculos e atualmente assumiu significados ingênuos que denotam uma espécie de fanatismo ou irracionalidade. Não se pode falar de mística em sua acepção original, pois o termo advindo do grego mustikós significava mistérios, em especial relacionava-se aos "mistérios de Elêusis" Foi Pseudo-Dionísio Areopagita quem modificou o significado do termo. A nova acepção foi fixada na Idade Média e consagrada pelos místicos cristãos posteriores. Seu Tratado da Teologia Mística foi um dos escritos mais lidos da Idade Média. Assim, "mística" diz respeito a uma forma superior de natureza religiosa ou religioso-filosófica, que se dá de modo supra-racional. Portanto a mística está estreitamente ligada à Filosofia Perene, sendo a primeira a constatação e compreensão supra-racional da última. 
relacionados à ideia de mística (Idem).

Se Dillip Loundo, no supracitado ensaio de 2007, relatou a influência da Índia e das correntes de pensamento indianas na poesia da autora, algo que não deixa de estar relacionado à mística, no sentido em que a poeta se voltava para um conhecimento que pretenderia "explicar" os mistérios da vida, Darcy Damasceno, em Cecília Meireles: O mundo Contemplado (1967), e Leila Gouvêa, em Pensamento e "Lirismo Puro" na Poesia de Cecilia Meireles (2008), também desenvolveram um pensamento sobre o caráter místico da poesia ceciliana. Leila Gouvêa aprofundou-se na tentativa de explicar o "Lirismo Puro" da poeta, enquanto que Damasceno abordou a manifestação "mística" de Meireles a partir da relação com o grupo de Festa.

Por tudo isso, o mar enquanto tema e símbolo na poesia de Cecília Meireles pode estar intrinsicamente relacionado à busca pelo Absoluto e à tentativa de compreensão dos "mistérios", o que traria o certo "ar místico" de parte da poesia ceciliana. É nesse sentido que se pretende observar os contornos que o mar assume no centro da poesia compreendida nos três primeiros livros da fase madura da autora, pelo que se utiliza aqui, muitas vezes, referências a textos de culturas diversas do extremo Oriente e de matrizes judaica e greco-latina a fim de ampliar as possiblidades de compreensão de seus poemas, corroborando a fruição estética.

\section{"E foi desde sempre o mar": o mar como tema e símbolo}

O título do livro Vaga música remete às ondas do mar e ao seu som, é desse livro o seguinte poema cujo trecho destaca-se abaixo:

Em Voz Baixa

(...) Mas não. Sempre mais comigo vou levando os passos meus, até me perder de todo no indeterminado Deus. (Vaga Música, 2001, p.353).

Nesse poema ocorre uma demonstração bastante explícita dada pela palavra "indeterminado" da ideia de Deus feita pelo eulírico. Segundo a Filosofia Perene, o Absoluto/ Deus é infinito e suas formas são inúmeras e vastas, de modo que está sempre em mutação, sendo assim impossível concebê-Lo ou compreendê-Lo totalmente. Na literatura sânscrita, muito admirada por Cecília Meireles ${ }^{4}$, encontramos algumas referências relevantes acerca da "indeterminação" do divino. $\mathrm{Na}$ Bhagavad-gita (que faz parte do poema épico Mababharata), por exemplo, ao ver a forma transcendental de Krishna, a Suprema Personalidade de Deus, o arqueiro-herói Arjuna perde a razão tamanha a potência e opulência do Absoluto. O guerreiro sente-se incapaz de conceber o esplendor divino e pede a Krishna que se mostre de modo mais simples para que possa contemplá-Lo (Bhagavad-gita, 2015, cap. 11, versos 5 a 55, p. 559-605). Em Cecília Meireles o divino é muitas figurado como essa grande força vasta, multiforme e impenetrável. Desse modo, em "Em voz baixa", temos que o eu-lírico decide

4 A proposta mística de Cecília foi enriquecida por meio de leituras sistemáticas, tanto de textos tradicionais hindus, quanto de escritores indianos. Segundo Dillip Loundo (que teve acesso à sua biblioteca) a autora leu desde a literatura sânscrita, clássica e antiga: os épicos Ramayana e Mahabharata; os textos dos Vedas e Upanishads, os Sutras, fábulas e sagas históricas. Passando pelo teatro e poesia, traduziu poetas místicos como Kabir, Mirabai e Tulsidas, clássicos como o livro de Simbad e As Mile Uma Noites. Além disso, leu muitos orientalistas franceses e também se deteve no folclore regional de algumas regiões da Índia. Leu escritos como os de Ramakrishna, Vivekananda, Aurobindo Gosh, Sarojíni Naidu, Abhay Khatau, entre outros. Dessas influências, as mais marcantes foram a do poeta ganhador do prêmio Nobel de 1913, Rabindranath Tagore, e a de Mahatma Gandhi. 
ir sozinho pelo seu próprio caminho até "perderse/confundir-se" com Deus, um deus que aqui surge sem adjetivações, aspecto que reforça o seu cariz misterioso e inapreensível.

Essa característica mutante e toda penetrante assumida pelo divino, nesse poema, relaciona-se muito proximamente com o movimento eterno das águas e a sua capacidade de adquirirem qualquer forma, seja quando retidas em um recipiente ou mesmo dada a possibilidade das suas alterações físicas, que passam do sólido ao gasoso, do gelo ao líquido, da nuvem à chuva. Todavia, a grandiosidade e a força do mar são talvez os mais precisos símbolos para tratar de tema tão impalpável. Mais um exemplo dessa indeterminação que nos leva para o Absoluto está em "Velho Estilo", também de Vaga Música:

(...)De ti só resta o que se consome. Vais para morte? Vais para a vida?

Tua presença n’alguma parte é já sinal da tua partida. E eu disse a todos desse teu fado, para esquecerem teu chamamento, saberem que eras constituída da errante essência da água e do vento. (Idem, p.357-358).

Nos versos acima, a "essência errante" da água e do vento e a ambiguidade do verso "de ti só resta o que se consome" amplificam a inexatidão de algo que é inapreensível e sem forma. Mais uma vez o fado de ser como água e como vento surge como tema, e a incerteza acerca do caminho revelam morte e vida como dois aspectos indissociáveis. Em Cecília Meireles, de modo muito sutil, a água toda penetrante vai assumindo várias formas até que ser mar, símbolo maior para o Absoluto, essência de tudo e de si mesmo que abarca toda a existência, ou seja, vida e morte:
(...) Deixa-te estar neste embalo de água gerando círculos Nem é preciso dormir, para a imaginação desmanchar-se em figuras ambíguas

Nem é preciso fazer nada, para se estar na alma de tudo.

Nem é preciso querer mais, que vem de nós um beijo eterno, e afoga a boca da vontade e os seus pedidos. (Viagem, 2001, p.255).

Em "Êxtase" há uma sugestão de relaxamento, pois o eu-lírico, estando sobre a água e "gerando círculos", sugere que ele mesmo é o centro de onde emanam as ondas. $\mathrm{O}$ verso seguinte remete à imaginação e aos processos da mente que, relacionados ao verso anterior, insinuam que as figuras ambíguas projetam-se em círculos da água. Até esse momento a água parece estar estreitamente ligada à mente/imaginação do eu-lírico, metaforizando o processo criativo. Tais conexões se amplificam se relacionarmos estes primeiros versos da citação ao conteúdo do Gênesis bíblico em que o espírito de Deus pairava sobre as águas e desse estado primordial adveio toda a criação. Adiante, esse estado de tranquilidade que ambiguamente gera movimento nas águas é tomado como espaço de conexão entre o eu-lírico e a totalidade do mundo. O verso "Nem é preciso fazer nada, para se estar na alma de tudo" reforça a ideia de êxtase indicada pelo título da composição. Inesperadamente as formas da imaginação, talvez sonhos/desejos, se consomem diante de tal êxtase. Afogadas pelas águas, as vontades sucumbem diante do infinito.

No que concerne às possibilidades de Exxtase compreensão do poema, é possível avançar para 
além das comparações com o mito de criação cristão, uma vez que a autora conhecia e estudava diversas culturas; tendo inclusive manifestado em carta a Armando Cortes-Rodrigues a sua vontade de lecionar religião comparada na universidade. Ao considerarmos que Meireles já conhecia muito bem várias das vertentes da cultura de língua sânscrita à altura da organização do livro Viagem, especialmente seus mitos, é possível colocar o poema ao lado do simbolismo da imagem de Narayana, divindade védica associada às águas.

No livro Bhagavata Purana (ou também conhecido como Śrimad Bhägavatam - "o livro de Deus"), da antiga cultura sânscrita, Narayana é descrito como sendo o centro de tudo, o supremo desfrutador (capítulo 9, v.18) e todas as austeridades, meditação, misticismo e busca por conhecimento transcendental se destinam a alcançá-lo (capítulo 5, v.16). Ainda nesse Purana, a divindade surge relacionada às águas quando é descrito que, no final dos tempos, Narayana se deita na água da devastação e submerge levando consigo toda a criação (capítulo 6, v.29). Já no livro Manusmriti (As leis de Manu, escrito em aproximadamente 1500 a.C), também da tradição sânscrita, temos que:

The waters are called narah, (for) the waters are, indeed, the offspring of Nara; as they were his first residence (ayana), he thence is named Narayana. From that (first) cause, which is indiscernible, eternal, and both real and unreal, was produced that male (Purusha), who is famed in this world (under the appellation of ) Brahman. (The laws of manu, s/d, trad. G. Buhler).

As águas são chamadas narah, (pois) as águas são, de fato, a prole de Nara; como eram sua primeira residência (ayana), decorre daí que se chama Narayana. Daquela (primeira) causa, que é indiscernível, eterna e real e irreal, foi produzido o masculino (Purusha), que é famoso neste mundo (sob o nome de) Brahman. (Tradução própria).

Assim, o poema de Cecília Meireles se redimensiona diante de tais informações, e o motivo da água pode ser lido como um modo de recriar poeticamente qualidades que em outros tempos já haviam sido configuradas literariamente em outras culturas de modo similar ao que nos sugere "Êxtase". Vemos, portanto, que já em Viagem a água é utilizada para dar forma ao informe, exprimindo ao leitor a fluidez e os contornos imprecisos do Absoluto. Sendo assim, a água assume variadas imagens no centro da poesia ceciliana, sendo o mar o aspecto central do presente estudo.

Em Viagem, dos cerca de 100 poemas, em pelo menos 21 deles há a ocorrência da palavra mar, desconsiderando o vocabulário náutico e as referências à água, que perpassam o livro todo. Nesse livro, o mar ainda não está posto como símbolo do Absoluto, mas suas características cantadas, como a imensidão, eternidade do movimento, capacidade de dar e tirar vida, já dão indícios da amplidão que o elemento receberia em Mar Absoluto. De modo que é no desenvolver dos três livros que o tema "mar" aos poucos transfigura-se em um símbolo. A passagem se dá de modo sutil. Ainda em Viagem lemos:

\section{Corpo no mar} Água densa do sonho, quem navega? Contra as auroras, contra as baías: barca imóvel, estrela cega.

Adeus a todos os meridianos! Deito-me como num caixão.

Ah! sobrevive o mar no meu ouvido... "Marinheiro! Marinheiro!"

(Ilhas... Pássaros... Portos — nesse ruído. — O mar!... O mar!... O mar inteiro) 
Mas é tempo perdido. (Idem, p.267).

Nesse caso, o eu-lírico dá a entender, na primeira estrofe, que sua navegação é pelas "águas do sonho". Todavia esse sonho/barco se desmonta até que reste apenas o corpo do eulírico dentro da barca à deriva. Assim, tomado pelo som do mar, boia como morto ao sabor das ondas salgadas. Sem mais velas que lhe permitam guiar a barca, o eu-lírico é tomado pela imensidão do mar em redor. Há o reconhecimento de que várias "formas" the chamam: "Ilhas... Pássaros, Portos", mas o marinheiro reconhece que, diante da falta das velas e dos remos, é tempo perdido tentar aproximar-se das figuras e talvez ele já esteja metaforicamente morto para esse mundo de chamados.

O barco no maré motivo bastante recorrente na poesia ceciliana, bem como o navegador. Esta viagem metafórica através dos sonhos representa a impossibilidade de alcançar os desejos e realizálos, ao mesmo tempo em que sugere aceitação e renúncia (morte). Assim, o eu-lírico compreende a sua situação no seio da imensidão do mar, remetendo à própria vida e seus (des)caminhos. A "viagem" a que se refere o título do livro no qual o poema foi publicado é mote para uma jornada em busca do encontro com o misterioso gerador da vida e também é metáfora para o domínio dos próprios desejos: das águas da própria mente. Se Fernando Pessoa como Alberto Caeiro se fez "pastor" e o seu rebanho era formado pelos seus pensamentos, Cecília Meireles compôs poeticamente marinheiros que tentam apaziguar as águas da mente.

De Viagem para Vaga Música, notou-se uma importante modificação dos temas marítimos, pois, no segundo livro, a atmosfera que permite a forte simbologia de "Mar Absoluto" começa a tomar maior corpo e decorre daí que o mar passa a ganhar forma simbólica. O primeiro poema do livro reforça a ambiguidade do título em que a palavra "vaga" pode ser também uma referência às ondas do mar:

Ritmo

O ritmo em que gemo doçuras e mágoas é um dourado remo por douradas águas (Vaga Música, 2001, p.328).

Neste livro de 1942, a autora dá contornos mais espessos às temáticas marinhas: "se alguém ouvir temos pena / só cantamos para o mar..." (Idem, p.329). Desse modo, mar, onda, remos, barco, marinheiro, águas de toda a sorte, praia, areia entre outros elementos marítimos, são o fio condutor de Vaga Música. É também nas composições desse livro que areia e mar, terra e água, começam a significar o equilíbrio entre o "mundo dos homens da Terra" (os que têm desejos) e o mundo dos homens do mar (os desprendidos/desapegados, portanto livres). Esta duplicidade entre mar e terra também remete ao dentro e fora, de modo que os eu-líricos cecilianos tentam equilibrar a introspecção (águas dos sonhos e imaginação) com a ação (mundo da areia e, consequentemente, metáfora essencial para efemeridade da vida cotidiana):

Canção Excêntrica Meu pé dançando pela extremidade da espuma e meu cabelo por uma planície de luz deserta

Sempre assim: de um lado, estandartes do vento... do outro, sepulcros fechados, 
e eu me partindo, dentro de mim, para estar no mesmo momento de ambos os lados. (Idem, p.336).

Logo, o mar passa a ser composto como detentor de todos os conhecimentos. Aos poucos vai assumindo as características do Absoluto, de modo que é a partir de Vaga música que a poeta cria os significados de seus símbolos, estreitamente conectados com a busca pelo mistério que rege a vida:

O mar, de língua sonora, sabe o presente e o passado. Canta o que é meu, vai-se embora: que o resto é apagado (Idem, p.386).

Suas escolhas filosóficas e seu conhecimento vasto de muitas culturas e religiões estão sutilmente refletidos em seus poemas de modo que, olhando para a totalidade dos três livros analisados aqui e para a sua biografia, ampliamse as possibilidades de compreensão de poemas que, por vezes, parecem muito herméticos.

Se em Vaga música os símbolos começam a existir como tal, vale delimitar o que se possa compreender por "simbólico", que nesse caso não se refere à prática da corrente Simbolista, ainda que Meireles tenha demonstrado certa afinidade com o Simbolismo em suas composições anteriores à Viagem. Entende-se aqui que Cecília Meireles fazia um uso assaz consciente de seus símbolos, dadas as repetições dos mesmos em poemas de conteúdos parecidos. A autora demonstra ainda bastante genuinidade nas suas escolhas.

O termo "símbolo" tem, na sua acepção mais comum, a designação de ser algo que se usa, ou se considera, como representativo de outra coisa, ou seja, o símbolo é diferente daquilo que é simbolizado. Para Jean Chevalier e Alain Gheerbrant: "um símbolo é muito mais do que um simples signo: transporta para lá da significação, depende da interpretação e, esta, de uma certa predisposição. Está carregado de afetividade" (CHEVALIER, GHEERBRANR, s/d, p.13). A função de um símbolo é, segundo Mircea Eliade, "revelar uma realidade total inacessível aos outros meios de conhecimento (...) o pensamento simbólico faz explodir a realidade imediata, mas sem diminuí-la ou desvalorizá-la" (ELIADE, 2002, p.177).

O uso do símbolo em Cecília Meireles parece ter a intenção da busca por significados em lugares além da razão; um discurso não simbólico seria menos penetrante e impactante. A sua opção para falar da questão do Absoluto foi a de expandir a realidade imediata, levando o leitor a um conhecimento ao qual não se pode chegar apenas conceitualmente.

Walter Benjamin, em Origem do Drama Barroco Alemão, afirmou acerca do símbolo nas artes plásticas:

O que chama atenção no uso vulgar do termo é que esse conceito, que aponta imperiosamente para a indissociabilidade de forma e conteúdo, passa a funcionar como uma legitimação filosófica da impotência crítica, que por falta de rigor dialético perde de vista o conteúdo, na análise formal, e a forma, na estética do conteúdo. Esse abuso ocorre sempre que numa obra de arte a “"manifestação' de uma 'ideia' é caracterizada como um símbolo". A unidade do elemento sensível e do supra-sensível, em que reside o paradoxo do símbolo teológico é deformada numa relação entre manifestação e essência. A introdução na estética desse conceito distorcido de símbolo foi uma extravagância romântica hostil à vida, que precedeu o deserto da moderna crítica de arte. (BENJAMIN, 1987, p.183).

Citando a definição de Creuzer para alegoria e símbolo, Benjamin recortou trechos que são importantes para o presente estudo. 
Segundo Benjamin, Creuzer propôs que a diferença entre símbolo e alegoria está numa questão que é temporal. Sob esse aspecto, no símbolo há uma totalidade momentânea que não ocorre na alegoria e Creuzer, ainda citado por Benjamin, conclui em uma passagem sobre os filósofos naturais jônicos que: "eles devolvem ao símbolo (...) as suas antigas prerrogativas. $\mathrm{O}$ símbolo (...), é mais apropriado que a saga para indicar o caráter uno e inefável da religião, devido à sua concisão significativa, a seu caráter total, e à exuberância concentrada de sua essência" (Idem, ibidem). Isso posto, podemos compreender a opção de Cecília Meireles pelos símbolos. Se para a autora o poeta era tal como profeta ou santo, seguindo certa tradição petrarquista, o símbolo auxiliaria sobremaneira a tarefa reveladora do ato poético.

Benjamin sublinhou que a ênfase de Creuzer no aspecto momentâneo do símbolo aponta para a verdadeira solução: "a medida temporal da experiência simbólica é o instante místico, no qual o símbolo recebe o sentido em seu interior oculto e por assim dizer, verdejante" (Idem, p.187. Grifos nossos). Apesar de a frase ser um tanto obscura, podemos compreendê-la melhor ao retomar a definição do conceito "místico(a)" proposto neste trabalho. Sendo "mística" a busca pelo Absoluto, o "instante místico" pode ser entendido como o momento do encontro. É nesse momento que o símbolo recebe seu sentido. Portanto, o símbolo em Cecília Meireles está bastante conectado com as definições de Benjamin sobre artes plásticas, uma vez que se refere àquilo que só pode ser apreendido fora do tempo, em um instante de êxtase (vide os poemas supracitados). Concomitante, simboliza as impossibilidades desse encontro, ou seja, o momento exato do descaminho e da profunda amargura e tristeza de reconhecer-se distante do encontro com "a alma de tudo" (tendo em vista que é tratado na poesia ceciliana tanto de modo pessoal, o Absoluto como sujeito portador de personalidade especialmente nos livros anteriores a Viagem, quanto impessoal: o Absoluto como essência dos seres e formas).

Entretanto não é possível fixar os limites de um símbolo, leia-se o que afirmou Marcel Raymond em De Baudelaire ao Surrealismo:

Parece que o espírito humano, no sonho,
no devaneio ou mesmo durante a vigília, é
dotado de um poder de criação autônomo,
que imagina livremente fábulas, figuras,
imagens, nas quais se projeta a afetividade
profunda do eu. Simbolismo espontâneo, ao
qual a razão ou diversos órgãos de censura,
nos civilizados, vêm colocar obstáculos,
mas que funciona quase sem controle nos
"primitivos" ou durante o sonho. (...)
O símbolo autêntico, de fato, nasce de uma
adesão direta do espírito a uma forma de
pensamento naturalmente figurada; "não
sendo nunca uma tradução, também não
pode nunca ser traduzido". (RAYMOND,
1997, p.42).

De fato, os símbolos autênticos, aqueles em que há a "totalidade momentânea" citada por Benjamin, são polivalentes. Nesse sentido, não se pode encerrar o mar de Cecília Meireles em uma fórmula. Pode-se considerar o trabalho do poeta de tomar consciência de um processo espontâneo, de um estado de alma e de lapidálo, redimensioná-lo e figurá-lo no poema simbolicamente. Este modo de utilização do símbolo não é novidade de Cecília Meireles, é, na verdade, um modelo antigo já muito usado pelos textos sagrados, veja-se os exemplos da tradição védica e mesmo cristã entre tantas outras.

O trabalho do poeta seria, portanto, o de uma espécie de tradutor do universo, da Natureza. Segundo Raymond (1997, p.19), Baudelaire, por exemplo, via na natureza exterior um imenso reservatório de analogias, resultando na ideia que toda a criação deve ser encarada como algo a ser 
decifrado, ou seja, deve-se descobrir o sentido oculto, a "realidade" das coisas para transitar no "além espiritual que banha o universo visível" (Idem, Ibidem). Podemos dizer que Cecília Meireles não se afasta dessa prática. A paralisação do instante, segundo o próprio Benjamin, é a essência do símbolo. O símbolo como captação do momento está ligado às artes plásticas (arte à qual o texto de Benjamin se refere), entretanto, a paralisação do momento é essencial também na poesia de Cecília Meireles (vide poemas como "Motivo", os Epigramas de Mar Absoluto, "Canção Mínima”, "Excursão" e "Serenata”). O que ocorre, na verdade, não é um total congelamento do ato, mas uma eternização do instante. Tal aspecto é simbolizado especialmente pelo uso de elementos do mundo natural.

Foi na fase madura da autora que os símbolos começaram a ganhar força e características próprias, dando singularidade à sua poesia. Meireles passou a usar elementos do mundo natural para exprimir as jornadas dos vários eu-líricos. A autora construiu em sua poética o ambiente para seus símbolos. Desse modo esteve afastada do uso do vocabulário modernista, que remetia às cidades e ao seu movimento, o que não significa que não tenha sido moderna a seu modo.

\section{O "Mar Absoluto"}

\section{É em Mar Absoluto e Outros Poemas,} portanto, que o mar enquanto símbolo se eleva com maior força. Diante da vastidão das possibilidades de interpretações para um símbolo, optou-se por restringir a busca de significados para a simbologia do mar em Cecília Meireles nas culturas portuguesa, sânscrita e na tradição greco-latina remetendo, em alguns casos, a mitos e culturas que contenham exemplos daquilo que se pretendeu demonstrar, visto que os conhecimentos culturais da poetisa eram bastante amplos.

Mar, Nau, Viagem, Descobrimento, Demanda, Oriente, Amor, Império, Saudade e Encoberto são palavras escolhidas por Antônio Quadros, em O Espirito da Cultura Portuguesa, como constituintes do ideário português (sendo a cada uma delas dedicada uma parte de seu livro) e, de certo modo, não se pode negar que estejam presentes em Cecília Meireles. De origem açoriana, tendo como primeiro marido um português, a escritora nunca escondeu sua admiração por Portugal (e também pela Índia) e são muitos os bons trabalhos críticos que tratam dessa proximidade, paixão e influências (como os trabalhos de Leila V.B. Gouvêa e Luísa Mota).

A posição geográfica de Portugal levou seu povo a sentir e exprimir o mar nas suas manifestações artísticas e literárias. Uma vez concluída a conquista da terra pátria (com as lutas contra os mouros), o mar passa a ser visto como a porta que se abria "da Ocidental praia Lusitana" para o mundo, e Portugal lançou-se na sua maior aventura em busca de conquistar os "mares nunca dantes navegados" (Camões, Canto I, est. I). O Cabo da Tormentas deu lugar ao Cabo da Boa Esperança e o mar Tenebroso deu lugar ao Mar Português. Em poucas décadas, Portugal contribuiu muito para uma profunda alteração nas experiências de troca entre povos (que nem sempre se deu de modo pacífico ou em níveis de igualdade) e, sobretudo, para a tecnologia de navegação. Decorre dessa experiência um dos ricos capítulos da literatura portuguesa: a literatura de viagem e o épico camoniano.

Não só Portugal manifestou literariamente a força do mar. Dentre tantos povos tomemos como exemplo a mitologia romana, em que o deus das águas e correntes é Netuno que, posteriormente, torna-se deus dos mares (sendo equivalente a Poseidon, da mitologia grega). Para Cícero, em seu De Natura Deorum, a 
palavra "Netuno" deriva do verbo "nadar" (nare) (CICERO, 1967, III. xxiv-xxv, p.347), todavia Varrão - em De lingua latina - assume que Neptunus deriva de nuptus (cobertura) e alude a derivação à palavra nuptiae (núpcias), o casamento do Céu e da Terra:

Neptunus, quod mare terras obnubuit ut nubes caelum, ab nuptu, id est opertione, ut antiqui, a quo nuptiae, nuptus dictus.

Neptune, because the sea veils the lands as the clouds veil the sky, gets his name from nuptus 'veiling,' that is, opertio 'covering,' as the ancients said. (VARRÃO, V.72, trad. KENT, 1938, p.69).

Netuno, porque o mar envolve a terra como nuvens envolvem o céu, tem o seu nome derivado de nuptus "velamento", isto é, opertio "cobrir", como disseram os antigos. (Tradução nossa a partir do original em latim).

A questão da etereidade/nebulosidade na poesia de Cecília Meireles, termos muito usados pela crítica, pode ser devido ao uso de um vocabulário marítimo que remete à etimologia latina do nome do deus do mar. Nome este também dado ao planeta que deve sua cor azul à alta concentração do elemento químico éter: Netuno. A escolha lexical remete ao místico e à nebulosidade. A própria autora usou tanto em crônicas quanto em poemas o adjetivo "nebuloso". Também se chamou "pastora de nuvens" e o termo foi apropriado pela crítica como alcunha para a poeta. Para além do éter, Netuno, o mar, tomando-se a ideia de Varrão, refere-se ainda a núpcias (Idem, ibidem). $\mathrm{Na}$ mitologia grega (conforme a Teogonia de Hesíodo),
Gaia cria Urano para cobri-la e de sua união com o céu nasceu o mar (HESÍODO, 2006). Nesse sentido, o mar é símbolo desse casamento entre Céu e Terra e também da geração da vida. $\mathrm{Na}$ poesia de Cecília Meireles não é diferente, uma vez que o equilíbrio entre nuvens, água e terra é um dos eixos temáticos da sua poesia.

Já segundo a tradição de língua sânscrita, especificamente com origem nos Vedas, Varuna é o deus do céu, da água e do oceano celestial (como se pode perceber por meio das mitologias citadas aqui, há essa noção de "oceano celestial" ou rio que envolve o mundo tanto acima da esfera celeste quanto abaixo do submundo). Sendo assim é considerado o deus de todas as formas do elemento água, principalmente dos oceanos. O Atharva-veda retrata essa divindade como um ser onisciente, "o divino observador", sendo que os céus e o oceano são partes de seu corpo (Atharvaveda, 1905, p.174). Ainda segundo esse veda, as estrelas são seus espiões de mil olhos (Idem, p.177), observando os homens, é ainda chamado também senhor dos “grilhões” (p.178), cujos nós/ correntes simbolizam a capacidade de prender ou libertar, de dar vida ou de tirá-la, tal como o mar. Georges Dumézil (1940) identificou Varuna com o deus grego Urano (Céu). Outras teorias tendem a identificá-lo com o deus grego Poseidon ou o romano Netuno. Varuna, portanto, guarda a alma dos afogados na mesma medida em que os afoga - assim como os mares cecilianos, que também estão repletos de vozes e rostos. Na poesia de Cecília Meireles, o mar tem também esse poder de dar e tirar a vida, principalmente em Viagem ${ }^{5}$.

5 Considerando-se a origem portuguesa de Cecília Meireles, ainda seria possível pensar em uma relação com a Nossa senhora Navegantes. A autora também tinha bom conhecimento sobre as práticas culturais de matriz africana, tendo publicado um livro intitulado Batuque, samba e macumba: estudos de gesto e ritmo, mas em suas crônicas e escritos tais como cartas, pouco mencionou sobre uma afinidade mais próxima com as mitologias dessa mesma matriz, diferentemente do que se dá com a mitologia judaico-cristã e indiana (amplamente mencionadas em suas cartas, crônicas e poemas), por isso o recorte desse trabalho não deu enfoque para divindades também relacionadas com a água Yemanjá e Mamãe Oxum. Todavia isso não exclui a possibilidade de aproximação. 


\section{Solidão}

Imensas noites de inverno, com frias montanhas mudas, é o mar negro, mais eterno mais terrível, mais profundo (...)

(Viagem, 2001, p.240).

\author{
Aceitação \\ (...) É mais fácil, também, debruçar os \\ olhos no oceano \\ e assistir, lá no fundo, ao nascimento mudo \\ das formas, (...) \\ (Idem, p.241).
}

\section{Canções do Mundo Acabado \\ (...) A água salgada me escuta \\ e mistura nas areias \\ meu pranto e o pranto da lua. \\ Penso no que me dizias, \\ e como falavas e como te rias... \\ Tua voz mora no mar: \\ (Vaga Música, 2001, p.347).}

\section{Vigilância}

A estrela que nasceu trouxe um presságio triste;

inclinou-se o meu rosto e chorou minha fronte:

que é dos barcos do meu horizonte?

(Mar Absoluto e Outros Poemas, 2001, p.549).

Esses são alguns exemplos de poemas nos quais o eu-lírico coloca-se diante do mar a esperar por alguém que não vem, ou alguém que já se foi e agora habita o mar, como se o mar fosse o lugar dos mortos ou dos que vão nascer. Esse tipo de relação com o mar está bastante próxima também daquela das cantigas medievais portuguesas, o mar enquanto portador da vida, ora a leva, ora a traz.

Todavia outras significações são possíveis. As águas ainda podem ser metáfora para o próprio pensamento que, assim como o mar, esconde amores e rostos. O mar ceciliano é atemporal, em Mar Absoluto e Outros Poemas, com a simbologia do mar já mais consolidada, dada toda a trajetória dos livros anteriores, lemos no poema "Compromisso":
Transportam meus ombros secular compromisso.

Vigílias do olhar não me pertencem;

trabalho dos meus braços

é sobrenatural obrigação.

(...)Esta sou eu — a inúmera.

Que tem de ser pagã como as árvores

e, como um druida, mística.

Com a vocação do mar, e com seus

símbolos.

Com o entendimento tácito, instintivo,

das raízes, das nuvens, dos bichos e dos arroios caminheiros. (Idem, p.463).

O mar e a sua simbologia, portanto, são a vocação desse eu-lírico que tem, sob esse aspecto, a capacidade de abarcar os sofredores, de conduzilos sobre suas ondas e de, num movimento ora suave, ora brusco, mas incessante, eternizá-los. É um processo que passa da angústia causada pela espera diante do mar, da confissão e desabafo à serenidade de quem atribuiu a si mesmo a força e imensidão do movimento eterno das águias. Diante dessas características, pode-se aproximar o mar ceciliano da representação de Varuna, rei dos oceanos e senhor da noite (PIKE, 1930, p.44). Representando a pureza etérea e a amplidão da Verdade Infinita; o mar destrói tudo o que interfere no crescimento da Consciência/ Verdade na mente.

Apesar da força do simbolismo do elemento marítimo na poesia ceciliana, foi apenas em Viagem que ocorreu a segunda aparição da palavra "mar" na poesia da autora. Em seus livros anteriores o "mar" ainda não era eixo central, o que reforça o fato de Meireles os ter excluído de sua Obra Completa organizada na década de 1950.

Em "Anunciação", poema de Viagem, lemos: "Toca essa música de seda, frouxa e trêmula/ que apenas embala a noite e balança as estrelas noutro mar". Nesses versos, as águas salgadas começam a assumir o mesmo significado 
que terão no poema "Mar Absoluto", ou seja, há um mar imensurável e atemporal para além daquele natural/terrestre,

Em Cecília Meireles é permanente a visão subjetiva do mar, não apenas do mar, mas de toda a realidade exterior. (...) $\mathrm{Na}$ ânsia de abarcar o mistério da vida, transfigura elementos do mundo exterior, em plano marcadamente impressionista, para apresentar uma visão renovada dos próprios sentimentos, dos aspectos e das forças da natureza. (AZEVEDO FILHO, 1979, p. 66).

No poema "Mar Absoluto", todos os elementos que vinham sendo moldados no decorrer dos livros anteriores se unem para configurar o grande símbolo do mar enquanto o Absoluto:

\footnotetext{
Foi desde sempre o mar,

E multidões passadas me empurravam como o barco esquecido.
}

Agora recordo que falavam

da revolta dos ventos,

de linhos, de cordas, de ferros,

de sereias dadas à costa.

E o rosto de meus avós estava caído pelos mares do Oriente, com seus corais e pérolas,

e pelos mares do Norte, duros de gelo.

Então, é comigo que falam,

sou eu que devo ir.

Porque não há ninguém,

não, não haverá mais ninguém

tão decidido a amar e a obedecer a seus mortos.

(...)

(Mar Absoluto e Outros Poemas, 2001, p.448).

Uma característica fundamental aparece já no primeiro verso, a atemporalidade: "Foi desde sempre o mar". Na primeira estrofe o destino do eu-lírico se apresenta: "E multidões passadas me empurravam"; tais multidões o empurram para o mar e a comparação "como a barco esquecido" o situa no ambiente do marítimo, ao sabor das ondas. Ocorre que, empurrado pelas multidões, o eu-lírico está à deriva e esquecido de si mesmo, navegando nesse mar desde um passado distante.

$\mathrm{Na}$ segunda estrofe, o primeiro verso ainda tem como sujeito "multidões passadas" e sugere a atração que o mar sempre exerceu sobre a humanidade. Os versos seguintes retomam elementos ligados à mitologia sobre o mar, repassada de geração em geração. A repetição de sons em 'v' e 's' e o vocabulário dessa estrofe evocam uma atmosfera de aventura e mistério suscitada pelo mar, remetendo ao som das ondas e ventos. O eu-lírico dá indícios de que está se lembrando aos poucos do fato que o colocou à procura de algo misterioso.

O oitavo verso do poema remete, novamente, ao passado, dessa vez evocado pela figura dos avós. Lembremos que os avós de Cecília Meireles eram de origem portuguesa, logo, assim como em Viagem, o mar surge com a ambiguidade típica com a qual foi tratado à época das Grandes Navegações: pode ao mesmo tempo tirar e dar a vida, é local de partida e regresso.

Nesta terceira estrofe, a ambiguidade é dada pelo rosto dos avós, que estão tanto no mar rico do Oriente, quanto nas condições adversas dos mares do Norte. Note-se ainda a importância desses dois elementos (Oriente e Norte): os mares do Norte referem-se, provavelmente, a Portugal e o "rico Oriente" possivelmente à Índia, China e Japão, locais cujas filosofias inspiraram a obra da autora. É lá que estão situados aqueles que influenciaram o eu-lírico, ligados à própria figura de Cecília Meireles, que se reconfigura em poesia. Mais; foi por meio das histórias contadas pela avó vinda do Norte que a autora travou contato com o mar do Oriente e suas riquezas. Na crônica "Meus Orientes", Cecília Meireles aponta para a importância que os objetos orientais trazidos de Portugal por sua avó tiveram na construção do imaginário que ela própria consolidou de locais como China e Índia. 
A quarta estrofe tem no primeiro verso o verbo "falar" no presente do indicativo. As mesmas multidões que "falavam" na primeira estrofe, agora falam. Esta alternância nos tempos verbais reflete a atemporalidade do mar, significa que presente e passado interagem e se sobrepõem, ou seja, não são considerados linearmente.

Adiante, o eu-lírico deve "obedecer seus mortos", ou seja, seu destino é mesmo o mar.

E tenho de procurar meus tios remotos afogados.

Tenho de levar-lhes redes de rezas, campos convertidos em velas,

barcas sobrenaturais

com peixes mensageiros

e cantos náuticos.

E fico tonta.

acordada de repente nas praias

tumultuosas.

E apressam-me, e não me deixam sequer

mirar

a rosa-dos-ventos.

(Idem, ibidem)

$\mathrm{Na}$ quinta estrofe, acima reproduzida, essa continuidade (própria do mar) assume um ar religioso dado pelo vocabulário. $\mathrm{O}$ mar representa o compromisso da humanidade em manter viva a "memória de seus mortos", ou seja, o comprometimento de transferir crenças de geração a geração. Esta relação com o passado se interrompe na quinta estrofe e passa para um presente contínuo. Inicia-se, então, a viagem do eu-lírico pelo mar, sem poder conferir a direção em que segue. Mais que isso, ir ao mar é a única possibilidade para o humano, o único objetivo possível ainda que se tenha esquecido dele: "Ao mar! - Disciplina humana para a empresa da vida!’. Assim impelido pela multidão, tonto, o eulírico se lança ao mar "livrando o corpo da lição frágil da areia!”. A terra é, em Cecília Meireles, oposta ao mar. Representa, portanto, a ilusão e os apegos mundanos ou o ego. Isso é reiterado na sétima estrofe para, na oitava, afirmarem-se as características do mar. Poderoso, atemporal, solitário, enquanto que a areia é frágil e, em outros poemas, relacionada ao tempo fugaz em que o eu-lírico não se vê como eterno:

\begin{abstract}
Queremos a sua solidão robusta, uma solidão para todos os lados, uma ausência humana que se opõe ao mesquinho formigar do mundo, e faz o tempo inteiriço, livre das lutas de cada dia.
\end{abstract}
O alento heróico do mar tem seu pólo secreto, que os homens sentem, seduzidos e medrosos.
O mar é só mar, desprovido de apegos, matando-se e recuperando-se, correndo como um touro azul por sua própria sombra, e arremetendo com bravura contra ninguém, e sendo depois a pura sombra de si mesmo, por si mesmo vencido. É o seu grande exercício.
(Idem, p.449)

\section{O eu-lírico mostra teruma relação sanguínea} com as vozes que o impelem para o mar. Já vimos a paixão de Cecília Meireles pela Índia e por Portugal, sabemos de seus laços sanguíneos com este país e que aquele era tido como sua pátria de espírito. Diante disso, identificada com as vozes poderosas (talvez sábios) o eu-lírico vai em direção ao mar. Aqui o mar ainda refere-se ao mar que banha a praia em sentido denotativo. E, mais uma vez, a terra representa um local de fracas ilusões e de monotonia: "mesquinho formigar do mundo". Na oitava estrofe avança-se para a solidão do mar que começa a ser construído como metáfora de algo maior. "Queremos a solidão robusta, / uma solidão para todos os lados": esta solidão pode ser entendida (tendo como base as estrofes seguintes) no sentido de o mar ser metáfora do ente primeiro e do infinito, origem de toda a criação, aquele que criou a si mesmo, 
como em quem joga com a própria sombra. Metamorfoseia-se sendo a ação, o executor e o objeto da própria ação e, por conseguinte, eterno.

Desse modo, o mar faz o tempo "inteiriço", portanto retira-se de um tempo fugaz. O mistério desse ser grandioso e solitário seduz o homem e, na duodécima estrofe, há a referência ao fato de o mar "jogar um jogo" com seu próprio corpo. Aqui pode-se fazer a ligação com uma anedota hindu que também explica o conceito de tat tvan asi (exemplificado anteriormente segundo Heinrich Zimmer). Brahma, o primeiro ser, estava completamente entediado em sua solidão. Então a partir de si mesmo criou Maya (Ilusão) com o propósito de se divertir. Uma vez que Maya existiu, esta lhe propôs um jogo. Brahma concordou e, seguindo as instruções de Maya, criou o sol e as estrelas, a lua e os planetas, a vida na Terra, os animais, os oceanos, a atmosfera, tudo. Então Maya tomou Brahma e o cortou em milhares de minúsculos pedaços. Ela colocou um pedaço de Brahma em cada ser e disse: "Agora o jogo começa! Eu vou fazer você esquecer o que você é e você deverá tentar encontrar a si mesmo".

Assim como ocorre com a natureza de Brahma, o Mar Absoluto de Meireles "desdobra suas visões" (ilusões), origina o múltiplo, mas não deixa de ser água (não perde sua essência primordial). O mar está como que dentro do próprio eu-lírico e tenta acordá-lo para a compreensão de que também ele (o eu-lírico) é mar. Então temos que:

\footnotetext{
E assim como água fala-me.

Atira-me búzios, como lembranças de sua vOz,

e estrelas eriçadas, como convite ao meu destino.

Não me chama para que siga por cima dele, nem por dentro de si: mas para que me converta nele mesmo. É o seu máximo dom.

(Idem, p.450)
}

Por um lado, o termo "búzio" remete à tradição africana do jogo de tradição divinatória - o que permitiria interpretar o verso "Atira-me búzios, como lembranças de sua voz" como uma manifestação do destino, do fado que impele o eu-lírico para o caminho inevitável rumo ao mar. Por outro lado, também é possível a aproximação com a tradição indiana dos búzios transcendentais. No livro Bhagavad Gita, por exemplo, há o "soar dos búzios". No início do épico todos soam seus búzios para anunciar o início da batalha, todavia apenas aqueles tocados por $\mathrm{K} \square \square \square \mathrm{a}$ e Arjuna (do outro lado da guerra) são descritos como "transcendentais". Segundo o mito, o soar dos búzios transcendentais indicava que a vitória estava ao lado de Arjuna. Desse modo, ao aproximarmos tais interpretações do poema, pode-se compreender que "a voz" (distante, portanto transcendente ao eu-lírico naquele momento) presente no ato de "atirar os búzios" também é um indicativo de que não havia chances de luta para o eu-lírico diante da força do mar Absoluto.

O mar chama o eu-lírico para que se "converta" nele mesmo (verso 66). A palavra "converter" é muito significativa, remetendo a uma união mística. Decorre então a modulação do mar como gerador de várias formas, de modo similar à simbologia de Narayana, anteriormente citada aqui para auxiliar na compreensão dos complexos contrastes que o mar recebe na poesia de Cecília Meireles. Narayana, portanto, é também o nome original para o Supremo Ser do qual tudo provém. Como explicado anteriormente, segundo o Bhagavata Purana, Narayana é o único senhor e além dele não há outro. Tal característica aparece nas seguintes estrofes do poema, em que o mar cria a si mesmo:

O mar é só mar, desprovido de apegos, matando-se e recuperando-se, correndo como um touro azul por sua 
própria sombra,

e arremetendo com bravura contra

ninguém,

e sendo depois a pura sombra de si mesmo, por si mesmo vencido. É o seu grande exercício.

Não precisa do destino fixo da terra, ele que, ao mesmo tempo, é o dançarino e a sua dança. (Idem, p.449)

Este mar (representação da unidade), diferente daquele mar dos mitos de seus mortos, não quer "arrastar" o eu-lírico, mas o aceita como a si próprio, "convertida em sua natureza" desprendida (como se Brahma finalmente desvendasse o jogo de Maya e reunisse seus pedaços). As palavras "desprendida" e "disponível" remetem ao processo pelo qual se dá a conversão: por meio da renúncia. Tal desapego objetiva atingir a consciência plena, ou seja, a transformação do ser naquilo que ele é, sempre foi e sempre será: eterno como o mar. Segue-se que o eu-lírico percebe que encontrou um mar muito maior do que aquele que outrora conhecera. Fora em busca de seus entes perdidos e nessa jornada conheceu um mar soberano e sublime. Recorda-se então da sua "herança de âncoras", talvez de prisões e em contraste se depara com algo "sobre-humano". Então diante do mar que a levaria quem sabe a Portugal ou à Índia, diante das leituras que falariam de seu passado, o mar que reboava na sua vidraça se retrai em pequena concha, pequena célula no reino do Mar Absoluto, aquele que tudo contém e tudo gera.

\section{Considerações finais}

Escolhendo a Filosofia Perene como uma das bases para as comparações feitas aqui, pudemos ampliar o horizonte de análises, não focando apenas na influência hindu, mas buscando ainda correspondências nas influências portuguesas e na tradição greco-latina, o que permitiu um maior uso de textos para buscar bases de comparação, fosse nos Vedas, na Bhagavad-gita ou nos mitos romanos, por exemplo.

Aos poucos, ao longo de Viagem, Vaga Música e Mar Absoluto e Outros Poemas, o mar foi se transmutando em símbolo do Absoluto, dado seu caráter de mistério e eterno movimento. Entre as possibilidades do eterno e o sofrimento dado pela transitoriedade, equilibra-se o eu-lírico ceciliano. Seu lugar de poeta está posto como meio entre o Absoluto e o homem comum, sem, no entanto, haver separação entre os dois. Tudo está contido no Absoluto e é por isso que pela simples contemplação da rosa, da gota de orvalho ou do pássaro e especialmente do mar é possível chegar à compreensão ou percepção do eterno.

Os símbolos em Cecília Meireles podem ter vários outros significados, não excludentes. Assim como os deuses da mitologia hindu, um símbolo pode incluir em si muitas noções sem suprimir nenhuma. Tentou-se mostrar como o mar pode também ter uma simbologia perene quando avaliado comparativamente tendo como objeto suas configurações no centro de diferentes manifestações literárias, mas isso não exclui $\mathrm{o}$ fato de que um símbolo como esse possa ser reinventado pelo próprio poeta e transformar-se em algo completamente novo.

No caso de Cecília Meireles, parece bastante forte e inegável a relação com a mitologia e o folclore, dadas as características e interesses da própria autora. Com base em seus depoimentos sabemos que ela preferia usar aquilo que o povo já tinha criado, pois acreditava que esse era o melhor modo de passar algum conhecimento.

A autora nos presenteou com o seu eulírico poeta, cantando o instante e evidenciando as dificuldades de equilibrar-se em um mundo em que a maioria de nós se percebe fadado à morte ao 
passo que o poeta, assim como o santo, é capaz de ver o eterno dentro de toda a transitoriedade do mundo material. Meireles versificou os vislumbres da eternidade, estando ao mesmo tempo "dentro e fora das horas", vivendo na terra e navegando no mar Absoluto, assumindo assim natureza toda penetrante da água e por isso ela mesma dizia:

Deixar que a pedra e o fogo e o ferro sejam segundo a sua natureza. Mas que a água e a sua melodia possam também ser ouvidas. Que, desde o princípio, o espírito de Deus era levado sobre as águas. A terra era vã e vazia. E as trevas cobriam a face do abismo. Como se lê no "Gênese". (MEIRELES, 1999, p.119)

Aceitando que há no mundo aquilo que é da natureza da pedra, do fogo e do ferro, Cecília Meireles elegeu a permeabilidade e fluidez da água como símbolo poético para a espiritualidade, concentrando no mar toda a potência da manifestação do Absoluto como provedor, mantenedor, destruidor e restaurador da vida.

\section{Referências}

Atharva-veda (vol. VII). Cambridge, Massachusetts: The Harvard Oriental Series, 1905. Disponível em: <http://upload.vedpuran. net/Uploads/73543Atharvaveda.pdf $>$. Acesso em: abril de 2017.

\section{AZEVEDO FILHO, Leodegário A. Poesia e} Estilo de Cecília Meireles. Rio de Janeiro: José Olympio, 1970.

BENJAMIN, Walter. Origem do drama barroco alemão. São Paulo: Editora Brasiliense, 1987.

Bhagavad gita: a canção do Divino Mestre. Trad. Rogério Duarte. São Paulo: Companhia da
Letras, 1998.

Bhagavad gita: como ela é. A.C. Bhaktivedanta Swami Prabhupada (trad. do sânscrito para o inglês). Valdomiro Vaz e Radhanatha Dasa (revisão para o português). São Paulo: The Bhaktivedanta Book Trust, 2015.

Bhagavata Purana (A Set of Two Volumes). Ramesh Menon (trad.). New Delhi: Rupa \& Co, 2011.

CAMOES, Luís Vaz de. Os Lusíadas. Lisboa: Editora Ulisseia, 1999.

CHEVALIER, Jean, CHEERBRANT, Alais. Dicionário de Símbolos. Lisboa: ed. Teorema, $\mathrm{s} / \mathrm{d}$.

CICERO, Marcus Tullius. De natura deorum. H. Rackham (trad). Cambridge, Massachusetts: Harvard University Press, 1967.

DAMASCENO, Darcy. Cecília Meireles: O mundo Contemplado. Rio de Janeiro: Orfeu, 1967.

DUMÉZIL, Georges. Mitra-Varuna: essai sur deux représentations indo-européennes de la souveraineté. (Bibliothèque de l'École des Hautes Études, Sciences religieuses, LVIe vol.). Paris: Leroux, 1940.

ELIADE, Mircea. Imagens e Símbolos: Ensaio sobre o Simbolismo Mágico- Religioso São Paulo: Martins Fontes, 2002.

FERRO, António G. Quadros. O Espírito da Cultura Portuguesa. Lisboa: SEC, 1967.

GOUVÊA, Leila V. B (org.) Ensaios sobre 
Cecília Meireles. São Paulo: Humanitas; Fapesp, 2007.

\section{Pensamento e "Lirismo Puro" na}

Poesia de Cecilia Meireles. São Paulo:

EDUSP, 2008.

Cecília em Portugal. São Paulo:

Iluminuras, 2001.

HESÍODO. Theogony and Works and Days. Ann Arbor (trad.). Michgan: The University Press, 2006.

HUXLEY, Aldous. A Filosofia Perene. Rio de Janeiro: Civilização Brasileira, 1971.

LOUNDO, Dilip. Cecília Meireles e a Índia: Viagem e Meditação Poética. In. Ensaios sobre Cecília Meireles. São Paulo: Humanitas; Fapesp, 2007, pp. 129-178.

MEIRELES, Cecília. Cecília Meireles: Poesia Completa.Org. Antonio Carlos Secchin. Rio de Janeiro: Nova Fronteira, 2001. 2 v.

. Crônicas de viagem 2. Org. Leodegário

A. de Azevedo Filho. Rio de Janeiro:

Nova Fronteira, 1999.

PIKE, Albert. Indo-Aryan deities and worship - as contained in The Rig Veda. The Supreme Council, $33^{\circ}$, Southern Jurisdiction of the United States of America, 1930.

RAYMOND, Marcel. De Baudelaire ao Surrealismo. Flúvia M. L. Moretto e Guacira Marcondes Machado (trad.). São Paulo: EDUSP, 1997.
Kent (trad.). Cambridge, Massachusetts: Harvard University Press, 1938. Disponível em: < https:// archive.org/details/onlatinlanguage01 varruoft >. Acesso em: abril de 2017.

De língua latina. Disponível em: $<$ http://www.thelatinlibrary.com/varro.html> . Acesso em abril de 2017.

ZIMMER, Heinrich. Filosofias da Índia. Trad. Nilton Almeida Silva, Cláudia Giovani Bozza e participação de Adriana Facchini de Cesare. São Paulo: Palas Athena, 2008.

Artigo enviado em: 30/04/2017

Aceite em: 31/07/2017

VARRO, M.T. On the latin language. Roland G. 